\title{
Kepemimpinan: Analisis Kualitas Kepala SMA Negeri Plus Provinsi Riau
}

\author{
H. Darmawan \\ Sekolah Menengah Atas Negeri Plus Provinsi Riau \\ darmawan.iwan21@yahoo.com \\ Karno Ariyanto \\ UIN Sultan Syarif Kasim Pekanbaru Riau \\ ari_natuna88@yahoo.co.id
}

\begin{abstract}
ABSTRAK
Tujuan dari penelitian ini adalah untuk mengetahui kualitas kepemimpinan kepala SMA Negeri Plus Provinsi Riau dan untuk mengetahui faktor-faktor yang mempengaruhi kualitas kepemimpinannya. Peserta dalam penelitian adalah 2 orang guru, 1 orang tua siswa dan 1 orang dari komite sekolah. Teknik pengumpulan data yang digunakan adalah wawancara, dokumentasi dan observasi. Analisa data menggunakan model Miles dan Huberman yaitu reduksi data, model data, dan penarikan/verifikasi kesimpulan. Penelitian ini menemukan bahwa: a) Kepala sekolah memiliki visi dalam meningkatkan kualitas SMANe Plus Porvinsi Riau. b) Kepala sekolah memiliki integritas, namun kurang maksimal. c) Kepala sekolah sudah memiliki dedikasi yang tinggi. d) Kepala sekolah memiliki keluhuran budi namun belum dilaksanakan sepenuhnya. e) Kepala sekolah memiliki jiwa rendah hati. f) Kepala sekolah kurang memiliki sikap keterbukaan terhadap bawahan. g) Kepala sekolah memiliki kreativitas yang tinggi. h) Kepala sekolah sudah menerapkan keadilan dalam memimpin. i) Kepala sekolah memiliki ketegasan yang tinggi. j) Kepala sekolah kurang memiliki rasa humor. k) Latar belakang pendidikan kepala sekolah S2 Manajemen Pendidikan UNJ. 1) Pengalaman menjabat sebagai kepala sekolah selama 13 tahun. m) Tipe kepemimpinan yang diterapkan situasional.
\end{abstract}

Kata Kunci: Kualitas, Kepemimpinan 


\section{PENDAHULUAN}

Sekolah sebagai lembaga pendidikan yang terbuka, sebagai sistem sosial, dan sekolah juga sebagai agen perubahan, bukan hanya harus peka pada penyesuaian diri, melainkan sekolah juga harus dapat mengantisipasi perkembanganperkembangan yang terjadi dalam kurun waktu. Salah satu kekuatan efektif dalam pengelolaan pendidikan di sekolah yang berperan penting dan bertanggung jawab menghadapi perubahan dan perkembengan adalah kepala sekolah.

Kepala sekolah sebagai orang yang bertanggung jawab terhadap pelaksanaan pendidikan dan pengajaran di lembaga pendidikan, harus memiliki kesiapan dan kemampuan untuk membangkitkan semangat kerja personal. Kepala sekolah sebagai pemimpin juga harus mampu menciptakan iklim dan suasana yang kondusif, aman, nyaman, tentram, menyenangkan, dan penuh semangat dalam bekerja bagi para pekerja dan para pelajar. Sehingga pelaksanaan pendidikan dan pengajaran dapat berjalan tertib dan lancar dalam mencapai tujuan yang diharapkan.

Kepala sekolah tidak hanya betanggung jawab atas kelancaran jalannya kegiatan sekolah, akan tetapi keadaan lingkungan madrasah dengan kondisi dan situasinya serta hubungannya dengan masyarakat sekitarnya merupakan tanggung jawabnya pula. Inisiatif dan kretifitas yang mengarah pada perkembangan dan kemajuan sekolah adalah merupakan tanggung jawab Kepala sekolah terhadap lembaga pendidikan yang dipimpinnya.

Keberhasilan kepala sekolah dalam memimpin tidak terlepas dari kepemimpinannya. Kepemimpinan itu merupakan suatu hal yang sangat penting dalam pengelolaan pendidikan di sekolah dan berkaitan dengan masalah sekolah dalam pengelolaan pendidikan secara efektif.
Kepemimpinan merupakan proses mengarahkan dan mempengaruhi para anggota dalam berbagai aktivitas di suatu organisasi. ${ }^{1}$ Proses di sini bagaimana pemimpin menggunakan pengaruhnya untuk memperjelas tujuan pada bawahannya, memotivasi mereka untuk mencapai tujuan dan membantu menciptakan suasana kerja para staf bisa produktif dalam bekerja.

Melihat pentingnya peranan kepemimpinan kepala sekolah bagi guruguru dan murid-murid, kepemimpinan kepala sekolah juga merupakan salah satu faktor yang dapat mendorong sekolah untuk dapat mewujudkan visi, misi, tujuan, dan sasaran sekolah melalui programprogram yang di laksanakan secara terencana dan bertahap. Oleh karena itu, Kepala sekolah dituntut memiliki kemampuan yang tangguh agar mampu mengambil keputusan dan prakasa untuk meningkatkan mutu sekolah secara efektif. $^{2}$

Menurut David Bakala seperti yang dikutip oleh Sudarwan Danim terdapat 10 (sepuluh) karakter kepemimpinan yang berkualitas yaitu memiliki visi, integritas, dedikasi, keluhuran budi, rendah hati, keterbukaan, kreativitas, keadilan, ketegasan dan rasa humor. ${ }^{3}$

Sekolah Menengah Atas (SMA) Negeri Plus Provinsi Riau merupakan salah satu SMA Negeri yang ada di Riau di mana SMA Negeri Plus ini langsung dikelola oleh Pemerintah Daerah Propinsi Riau. Dalam 3 tahun terakhir ini SMA Negeri Plus Propinsi Riau yang mempunyai pretasi yang sangat bagus di tingkat provinsi, nasional bahkan di tingkat internasional. Prestasi-prestasi yang diraih antara lain:

\section{Juara 1 Engineering Physics Challenge ITS}

2. Juara 1 Speech Contest

3. Juara 1 Lomba Karya Tulis Ilmiah Lawatan Sejarah Daerah BPNB Tanjung Pinang se-Propinsi Riau, 
Kepualauan Riau, Jambi dan Kepulauan Bangka Belitung di Muoro Jambi 2013.

4. Juara 3 LDBI Nasional 2012

5. Mewakili Indonesia mengikuti Olimpiade Fisika di Kazakstan dan Astronomi di Rumania

Selain prestasi-prestasi yang disebutkan di atas, masih banyak lagi prestasi yang diraih oleh siswa-siswi Sekolah Menengah Atas (SMA) Negeri Plus Propinsi Riau.

\section{KERANGKA TEORITIS}

Kepemimpinan adalah proses kegiatan seseorang yang memiliki seni atau kemampuan untuk mempengaruhi, mengkoordinasikan dan menggerakkan individu supaya timbul kerja sama secara teratur dalam upaya mencapai tujuan bersama yang telah ditetapkan atau dirumuskan.

Kepala sekolah adalah "seorang tenaga fungsional guru yang diberi tugas untuk memimpin suatu sekolah di mana diselenggarakan proses belajar mengajar, atau tempat di mana terjadi interaksi antara guru yang memberi pelajaran dan murid yang menerima pelajaran" ${ }^{4}$

Sedangkan menurut Peraturan Menteri Pendidikan Nasional Nomor 28 Tahun 2010 Pasal 1 kepala sekolah adalah guru yang diberi tugas tambahan untuk memimpin Taman KanakKanak/Raudhotul Athfal Kluar Biasa (TKLB), Sekolah Dasar/Madrasah Ibtidaiyah (SD/MI), Sekolah Dasar Luar Biasa (SDLB), Sekolah Menengah Pertama/Madrasah Tsanawiyah (SMP/MTs), Sekolah Menengah Pertama Luar Biasa (SMPLB), Sekolah Menengah Atas/Madrasah Aliyah (SMA/MA), Sekolah Menengah Kejuruan/Madrasah Aliyah Kejuruan (SMK/MAK), atau Sekolah Menengah Atas Luar Biasa (SMALB) yang bukan Sekolah Bertaraf Internasional (SBI) atau yang tidak dikembangkan menjadi Sekolah Bertaraf Internasional (SBI). ${ }^{5}$

Dari definisi di atas dapat diambil pengertian bahwa yang dimaksud dengan kepemimpinan kepala sekolah adalah kemampuan kepala sekolah dalam mempengaruhi, membimbing, mengarahkan, mengajak, mendorong bawahannya untuk bekerja sama dalam mencapai tujuan sekolah yang telah ditetapkan.

1. Persyaratan kepribadian kepemimpinan kepala sekolah

Sebagai seseorang pemimpin, tentu saja diharapkan memiliki kelebihankelebihan daripada orang yang dipimpinnya. Oleh karena itu kepemimpinan kepala sekolah nantinya selalu berhadapan dengan orang lain dalam konteks sosial, maka ia harus memiliki persyaratan kepemimpinan kepribadian tertentu.

Menurut Peraturan Menteri Pendidikan Nasional Republik Indonesia Nomor 13 Tahun 2007 tentang Standar Kepala Sekolah/Madrasah menyebutkan kompetensi kepribadian yang harus dimiliki oleh seorang kepala sekolah adalah:

a. Berakhlak mulia, mengembangkan budaya dan tradisi akhlak mulia dan menjadi teladan akhlak mulia bagi komunitas di sekolah/madrasah.

b. Memiliki integritas kepribadian sebagai pemimpin.

c. Memiliki keinginan yang kuat dalam pengembangan diri sebagai kepala sekolah madrasah.

d. Bersikap terbuka dalam melaksanakan tugas dan fungsi.

e. Mengendalikan diri dalam menghadapi masalah dalam pekerjaan sebagai kepala sekolah/madrasah.

f. Memiliki bakat dan minat jabatan sebagai pemimpin pendidikan. ${ }^{6}$

Jika semua prasyaratan kepribadian kepemimpinan kepala sekolah sebagaimana tersebut di atas dimiliki oleh seorang pemimpin, maka ia akan dapat menjalankan kepemimpinannya dengan baik. Oleh karena itu, setiap kepemimpinan kepala sekolah hendaknya berusaha memiliki sifat-sifat kepribadian tersebut. 
2. Kompetensi kepemimpinan kepala sekolah

Kompetensi kepemimpinan dalam hal ini kepala sekolah harus memiliki kemampuan untuk dapat memimpin lembaga pendidikan atau untuk meningkatkan kualitas pendidikannya yang efektif dalam bingkai Manajemen Berbasis Sekolah (MBS).

Terkait dengan itu Sudarwan Danim menyatakan bahwa ada beberapa keterampilan kepemimpinan kepala sekolah, di antaranya: keterampilan teknis (technical skill), keterampilan hubungan manusiawi (human relation skill), dan keterampilan konseptual (conceptual skill). ${ }^{8}$

a. Keterampilan teknis, adalah keterampilan menerapkan pengetahuan teoretis ke dalam tindakan praktis, kemampuan memecahkan masalah melalui taktik yang baik, atau kemampuan menyelesaikan tugas secara sistematis.

b. Keterampilan hubungan manusiawi, adalah keterampilan untuk menempatkan diri di dalam kelompok kerja dan keterampilan menjalin komunikasi yang mampu menciptakan kepuasan kedua belah pihak.

c. Keterampilan konseptual, adalah kecakapan untuk memformulasikan pikiran, memahami teori-teori, melakukan aplikasi, melihat kecenderungan berdasarkan kemampuan teoretis dan yang dibutuhkan di dalam dunia kerja.

3. Kualitas kepemimpinan kepala sekolah

David Hakala seperti yang dikutip

Sudarwan Danim mengemukakan 10 karakter kepemimpinan yang berkualitas, di antaranya: ${ }^{9}$

a. Envision atau memiliki visi. Seorang pemimpin dengan visi yang jelas, memahami gambaran akan ke arah mana dan ingin menjadi seperti apa orgnisasi ke depan, serta bagaimana cara mencapainya.

b. Integrity atau integritas. Seorang pemimpin harus memiliki kepercayaan dari pengikut dan karenanya harus menampilkan integritas. JSeorang pemimpin yang berpegang tinggi pada integritas akan lebih mudah didekati oleh pengikutnya.

c. Dedication atau dedikasi. Dedikasi berarti menghabiskan waktu atau energy apa saja yang diperlukan untuk menyelesaikan tugas yang menjadi tanggung jawabnya.

d. Magnanimity atau keluhuran budi. Seorang pemimpin yang bermurah hati memastikan bahwa sumbangan keberhasilan tersebar luas mungkin pada semua orang di organisasinya.

e. Humility atau rendah hati. Seorang pemimpin yang rendah hati tidak akan menonjolkan diri melainkan mencoba untuk mengangkat semua orang.

f. Openness atau keterbukaan. Pemimpin yang baik mampu menangguhkan penilaian saat mendengarkan ide-ide orang lain, serta menerima cara-cara baru dalam melakukan sesuatu yang orang lain pikirkan.

g. Creativity atau kreativitas. Kreativitas pemimpin akan membuat dirinya mampu melihat hal-hal lain yang tidak di lihat oleh bawannya kea rah yang lebih maju.

h. Fairness atau keadilan. Seorang pemimpin harus memeriksa semua fakta dan mendengarkan semua orang sebelum memberikan penilaian. Ketika orang diperlakukan secara adil, mereka akan mengapresiasi pemimpin mereka dengan loyalitas dan dedikasi.

i. Assertiveness atau ketegasan. Seorang pemimpi harus bersikap tegas untuk memperoleh hasil yang diinginkan. Ketegasan datang bersama tangungjawab untuk secara jelas memahami apa yang pengikut harapkan dari pemimpinnya.

j. Sense of humor atau rasa humor. Pemimpin yang efektif mengetahui bagaimana menggunakan humor untuk member energi pengikutnya. Humor adalah suatu bentuk kekuasaan yang 
menyediakan kontrol atas lingkungan kerja.

4. Faktor-faktor yang mempengaruhi kepemimpinan kepala sekolah

Faktor-faktor yang pada umumnya sangat dominan mempengaruhi perilaku seorang pemimpin, di antaranya:

a. Keahlian dan Pengetahuan yang dimiliki oleh pemimpin untuk menjalankan kepemimpinannya. Yang termasuk dalam hal ini adalah latar belakang pendidikan atau ijazah yang dimiliki, apakah sudah sesuai dengan tugas-tugas kepemimpinan yang menjadi tanggung jawabnya; pengalaman kerja sebagai pemimpin, apakah sudah mendorong dia untuk berusaha memperbaiki dan mengembangkan kecakapan dan keterampilan dalam kepemimpinannya.

b. Jenis pekerjaan atau lembaga tempat memimpin melaksanakan tugas jabatannya. Tiap organisasi atau lembaga yang tidak sejenis memiliki tujuan yang berbeda dan menuntut caracara pencapaian tujuan yang tidak sama. Oleh karena itu, tiap jenis lembaga memerlukan perilaku dan sikap kepemimpinan yang berbeda pula.

c. Sifat-sifat kepribadian pemimpin. Secara psikologis, manusia mempunyai sifat, watak dan kepribadian yang berbeda-beda. Ada yang selalu dapat bersikap dan bertindak keras dan tegas, tetapi ada pula yang lemah dan kurang berani.

d. Sifat-sifat kepribadian pengikut atau kelompok yang dipimpinnya. Perbedaan sifat-sifat individu dan sifatsifat kelompok sebagai anak buah atau pengikut seorang pemimpin akan mempengaruhi bagaimana seyogyanya perilaku dan sikap pemimpin itu dalam menjalankan kepemimpinannya.

e. Sangsi-sangsi yang ada di tangan pemimpin. Kekuatan-kekuatan yang ada di belakang pemimpin menentukan sikap dan tingkah lakunya. Hal ini dapat dikatakan bahwa tinggi rendahnya tingkat kekuasaan dan atau perangkat perundang-undangan menentukan tinggi rendahnya kekuatan atau sangsi seorang pemimpin yang diangkat oleh penguasa atau berdasarkan perundangan tersebut.

\section{METODE PENELITIAN}

Jenis penelitian ini adalah kualitatif Penelitian ini dilaksanakan di SMA Negeri Plus Provinsi Riau. Adapun informan dalam penelitian ini berjumlah 5 orang yang terdiri dari: kapala sekolah, 2 orang guru, 1 orang tua siswa dan 1 orang dari komite sekolah. Pengumpulan data dilakukan dengan wawancara, observasi dan dokumentasi. Dalam pengujian kredibelitas data digunakan triangulasi data yakni triangluasi sumber, triangulasi metode, dan triangulasi teori. Data dalam penelitian ini dianalisis dengan menggunakan model Miles dan Huberman yakni, data reduction (Reduksi data, data dispalay (Model data), dan consclusion drawing/verification (Penarikan/Verifikasi kesimpulan)

\section{PEMBAHASAN}

Setelah penulis melakukan wawancara dengan responden yang menjadi subjek dalam penelitian ini yaitu kepala sekolah, 1 orang guru yaitu guru bidang studi sejarah dan 1 orang guru, orang tua dan komite sekolah dengan mengajukan beberapa pertanyaan yang berhubungan dengan penelitian ini, maka penulis memberikan analisis tentang kualitas kepemimpinan adalah sebagai berikut:

1. Memiliki visi

Berdasarkan hasil wawancara dan observasi yang penulis lakukan kepada para responden mengenai visi yang dimiliki kepala sekolah dalam meningkatkan kualitas Sekolah Menengah Atas (SMA) Negeri Plus Provinsi Riau, dapat diambil kesimpulan sementara bahwa kepala sekolah memiliki visi dalam meningkatkan kualitas Sekolah Menengah 
Atas (SMA) Negeri Plus Provinsi Riau, di mana visi kepala sekolah itu disesuaikan dengan visi Sekolah Menengah Atas (SMA) Negeri Plus Provinsi Riau itu sendiri yakni menjadikan Sekolah Menengah Atas (SMA) Negeri Plus Provinsi Riau yang menghasilkan Sumber Daya Manusia (SDM) Bertaraf Internasional, berwawasan Lingkungan Berlandaskan Imtaq dan Budaya Melayu.

2. Memiliki integritas

Berdasarkan hasil wawancara dengan responden, didapatkan kesimpulan sementara bahwa secara umum kepala sekolah dipercayai oleh bawahan, namun secara khusus terutama masalah keuangan bawahan tidak mempercayai kepala sekolah dikarenakan kepala sekolah tidak terbuka dalam masalah keungan tersebut.

3. Memiliki dedikasi

Berdasarkan wawancara dengan responden, maka dapat diambil kesimpulan sementara bahwa kepala sekolah memiliki dedikasi hal ini dibuktikan dengan adanya kedekatan kepala sekolah dan bawahan, kepala sekolah berkomitmen dan melaksanakan tugas tepat waktu, serta memberikan inspirasi kepada bawahan agar melaksanakan tugas dengan tepat waktu dan tidak melalaikan tugas yang telah diberikan.

4. Memiliki keluhuran budi.

Berdasarkan hasil wawancara dengan responden, maka diperoleh kesimpulan sementara bahwa kepala sekolah memiliki keluhuran budi. Ini dibuktikan dengan: a) Adanya pemberian penghargaan kepada bawahan yang memiliki prestasi kerja dan sanksi kepada bawahan yang melanggar disiplin sekolah, b) Ketika adanya kegagalan dalam pelaksanaan kegiatan maka kepala sekolah akan bekerja sama dengan bawahan untuk mencari solusi.

5. Rendah hati.

Dari wawancara dengan responden, diperoleh kesumpulan sementara bahwa kepala sekolah memiliki jiwa rendah hati. Hal ini dibuktikan bahwa kepala sekolah pernah mengakui jika bawahan lebih pintar dari dirinya.

6. keterbukaan.

Berdasarkan hasil wawancara dengan responden, maka didapatkan kesimpulan sementara bahwa kepala sekolah memiliki sikap keterbukaan, namun dalam hal keuangan kepala sekolah kurang terbuka. Hal ini dibuktikan dengan kepala sekolah menerima dan menampung ide-ide baru yang disampaikan oleh para bawhan dan dibahas ketika ada rapat dan diskusi sekolah.

7. kreativitas.

Berdasarkan wawancara dengan responden, maka didapatkan kesimpulan semantara bahwa kepala sekolah memiliki kreativitas. Hal ini dibuktikan dengan cepat dan tanggapnya kepala sekolah dalam mencari alternatif solusi pemecahan masalah, yang dilakukan secara bersamasama dengan komponen sekolah.

8. keadilan.

Berdasarkan hasil wawancara yang dilakukan kepada responden, maka diperoleh kesimpulan sementara bahwa kepala sekolah sudah menerapkan keadilan kepada bawhan. Hal ini dibuktikan dengan: a) kepala sekolah memberikan penilaian yang objektif kepada bawahannya, artinya dalam memberikan penilaian kepala sekolah tidak pilih kasih. b) Kepala sekolah membagi tugas kepada bawahan sesuai dengan kemampuan yang dimiliki oleh bawahan.

9. ketegasan.

Dari hasil wawancara dengan repsonden, maka diperoleh kesimpulan sementara bahwa kepala sekolah memiliki ketegasan kepada bawahan, hal ini dibuktikan dengan adanya ketegasan kepala sekolah terhadap bawahan terutama dalam pelaksanaan tugas, kemudian langsung menindak lanjuti bawahan yang malanggar aturan atau disiplin sekolah.

10. Rasa humor.

Berdasarkan hasil wawancara dengan responden, maka diperoleh kesimpulan sementara bahwa kepala kurang memiliki rasa humor kepada bawahan, hal ini 
dibuktikan dari hasil wawancara bahwa kepala sekolah ketika berkumpul dengan bawahan hanya membahas masalahmasalah sekolah saja.

Selanjutnya faktor-faktor yang mempengaruhi kualitas kepemimpinan kepala Sekolah Menengah Atas (SMA) Negeri Plus Provinsi Riau adalah:

1. Latar belakang penidikan kepala sekolah, yakni Lulusan S2 Manajemen Pendidikan Universitas Negeri Jakarta.

2. Pengalaman menjambat sebagai kepala sekolah, yakni sudah menjabat sebagai kepala sekolah selama 13 tahun, dan di Sekolah Menengah Atas (SMA) Negeri Plus Provinsi Riau selama 5 tahun

3. Tipe kepemimpinan yang diterapkan tipe demokrasi dan situasional.

\section{PENUTUP}

Setelah semua tahap penelitian dilakukan, mulai dari pembuatan proposal penelitian, kemudian pengkajian teori, penyusunan instrumen penelitian sampai dengan pengumpulan data, pengolahan dan analisis data. Pada akhirnya peneliti dapat

\section{DAFTAR PUSTAKA}

Imron Fauzi, Manajemen Pendidikan Ala Rasulullah, (Jogjakarta: Ar-Ruzz Media), 2012.

Mulyasa, Kurikulum Berbasis Kompetensi Konsep Karakteristik dan Implementasi, (Bandung: PT. Remaja Rosda Karya), 2005.

Mulyono, Manajemen Administrasi dan Organisasi Pendidikan, (Jogjakarta: Ar-Ruzz Media), 2008.

Peraturan Menteri Pendidikan Nasional Nomor 28 Tahun 2010 Tentang Penugasan Guru sebagai Kepala Sekolah/Madrasah

Peraturan Menteri Pendidikan Nasional Republik Indonesia Nomor 13 Tahun 2007 tentang Standar Kepala Sekolah/Madrasah. menyimpulkan bahwa: Kualitas kepemimpinan kepala Sekolah Menengah Atas (SMA) Negeri Plus Porvinsi Riau, yakni: a) Sudah memiliki visi dalam meningkatkan kualitas SMANe Plus Porvinsi Riau. b) Kepala sekolah memiliki integritas, namun kurang maksimal. c) Kepala sekolah sudah memiliki dedikasi yang tinggi. d) Kepala sekolah memiliki keluhuran budi namun belum dilaksanakan sepenuhnya. e) Kepala sekolah memiliki jiwa rendah hati. f) Kepala sekolah kurang memiliki sikap keterbukaan terhadap bawahan. g) Kepala sekolah memiliki kreativitas yang tinggi. h) Kepala sekolah sudah menerapkan keadilan dalam memimpin. i) Kepala sekolah memiliki ketegasan yang tinggi. j) Kepala sekolah kurang memiliki rasa humor, k) Latar belakang pendidikan kepala sekolah S2 Manajemen Pendidikan UNJ. 1) Pengalaman menjabat sebagai kepala sekolah selama 13 tahun. m) Tipe kepemimpinan yang diterapkan situasional.

Sudarwan Danim, Kepemimpinan Pendidikan; Kepemimpinan Jenius (IQ+EQ), Etika, Perilaku Motivasional, dan Mitos, (Bandung: Alfabeta), 2010.

Sudarwan Danim, Visi Baru Manajemen Sekolah; Dari Unit Birokrasi ke Lembaga Akademik, (Jakarta: Bumi Aksara), 2008, h. 215

Wahjosumidjo, Kepemimpinan Kepala Sekolah; Tinjauan Teoretik dan Permasalahannya, (Jakarta: RajaGrafindo Persada), 2005.

1 Imron Fauzi, Manajemen Pendidikan Ala Rasulullah, (Jogjakarta: Ar-Ruzz Media), 2012, h. 215

${ }^{2}$ Mulyasa, Kurikulum Berbasis Kompetensi Konsep Karakteristik dan Implementasi, (Bandung: PT. Remaja Rosda Karya), 2005, h. 182 
H. Darmawan, Karno Ariyanto: Kepemimpinan: Analisis Kualitas Kepala ...

3 Sudarwan Danim, Kepemimpinan

Pendidikan; Kepemimpinan Jenius $(I Q+E Q)$,

${ }^{4}$ Etika, Perilaku Motivasional, dan Mitos, (Bandung: Alfabeta), 2010, h. 334-37

5 Wahjosumidjo, Kepemimpinan Kepala Sekolah; Tinjauan Teoretik dan Permasalahannya, (Jakarta: RajaGrafindo Persada), 2005, h. 83.

6 Peraturan Menteri Pendidikan Nasional Nomor 28 Tahun 2010 Tentang Penugasan Guru sebagai Kepala Sekolah/Madrasah

7 Peraturan Menteri Pendidikan Nasional Republik Indonesia Nomor 13 Tahun 2007 tentang Standar Kepala Sekolah/Madrasah

8 Mulyono, Manajemen Administrasi dan Organisasi Pendidikan, (Jogjakarta: Ar-Ruzz Media), 2008, h. 153

9 Sudarwan Danim, Visi Baru Manajemen Sekolah; Dari Unit Birokrasi ke Lembaga Akademik, (Jakarta: Bumi Aksara), 2008, h. 215 